\title{
An information and communication technology adoption framework for small, medium and micro-enterprises operating in townships South Africa
}

\begin{tabular}{|c|c|}
\hline \multicolumn{2}{|c|}{$\begin{array}{l}\text { Authors: } \\
\text { Stella Bvuma }{ }^{1} \\
\text { Carl Marnewick }^{1}\end{array}$} \\
\hline \multicolumn{2}{|c|}{$\begin{array}{l}\text { Affiliations: } \\
{ }^{1} \text { Applied Information } \\
\text { Systems, College of Business } \\
\text { and Economics, University of } \\
\text { Johannesburg, Johannesburg, } \\
\text { South Africa }\end{array}$} \\
\hline \multicolumn{2}{|c|}{$\begin{array}{l}\text { Corresponding author: } \\
\text { Carl Marnewick, } \\
\text { cmarnewick@uj.ac.za }\end{array}$} \\
\hline \multicolumn{2}{|c|}{$\begin{array}{l}\text { Dates: } \\
\text { Received: } 10 \text { Feb. } 2020 \\
\text { Accepted: } 02 \text { June } 2020 \\
\text { Published: } 20 \text { Aug. } 2020\end{array}$} \\
\hline \multicolumn{2}{|c|}{$\begin{array}{l}\text { How to cite this article: } \\
\text { Bvuma, S. \& Marnewick, C., } \\
\text { 2020, 'An information and } \\
\text { communication technology } \\
\text { adoption framework for } \\
\text { small, medium and } \\
\text { micro-enterprises operating in } \\
\text { townships South Africa', } \\
\text { Southern African Journal of } \\
\text { Entrepreneurship and Small } \\
\text { Business Management 12(1), } \\
\text { a318. https://doi. } \\
\text { org/10.4102/sajesbm. } \\
\text { v12i1.318 }\end{array}$} \\
\hline \multicolumn{2}{|c|}{$\begin{array}{l}\text { Copyright: } \\
\text { (C) 2020. The Authors } \\
\text { Licensee: AOSIS. This } \\
\text { is licensed under the } \\
\text { Creative Commons } \\
\text { Attribution License. }\end{array}$} \\
\hline \multicolumn{2}{|l|}{ Read online: } \\
\hline 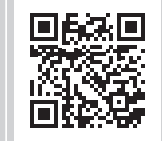 & $\begin{array}{l}\text { Scan this QR } \\
\text { code with your } \\
\text { smart phone or } \\
\text { mobile device } \\
\text { to read online. }\end{array}$ \\
\hline
\end{tabular}

Background: Small, Medium and Micro Enterprises (SMMEs) have been regarded as one of the critical driving forces for economic growth and development in South Africa (SA). In South Africa, SMMEs operate in townships and cities. However, there have been concerns about their failure rate and their inability to gain competitive advantage especially in the current era of rapid information and communication technologies (ICT) adoption.

Aim: This study aims to gain a deeper understanding of the factors affecting ICT adoption by township SMMEs. To further develop an ICT adoption framework for township SMMEs and provide guidelines to policy developers with the aim to increase growth and development.

Setting: The study examined the context of SMMEs in townships and explored ICT adoption theories or models so as to understand what factors are relevant in influencing ICT adoption by township SMMEs. A conceptual ICT adoption framework for township SMMEs was developed using Actor network theory (ANT) and Technology Acceptance Model (TAM).

Method: A qualitative exploratory research method is adopted as it provides insight into the SMME characteristics and their level of ICT adoption and perceptions. The study used a sample of 21 SMME owners or managers operating in Soweto. Data was collected using indepth interviews and observations.

Results: This study revealed that ICT adoption for township SMMEs is a complex and dynamic process which involves various factors. Township SMMEs are not adopting ICTs and the current ICTs adopted are not fully deployed. The perception of ICT adoption is equally influenced by external factors such as ICT support and ICT training amongst others. These actors drive the perceived benefits such as growth and sustainability which then influence the ICT adoption.

Conclusion: Township SMMEs requires unique interventions when encouraging them to fully adopt ICTs. They may adopt if correct guidelines are addressed such as ICT awareness and ICT training. The ICT adoption framework included factors that can be used by SMME owners or managers and policy makers when formulating guidelines towards ICT adoption for township SMMEs.

Keywords: ICT adoption; SMME; sustainability; framework; technology acceptance model (TAM); actor network theory (ANT).

\section{Introduction}

Economies around the world have acknowledged and recognised the importance of small, medium and micro-enterprises (SMMEs) and the role they play towards economic growth and development in both developed and developing countries (Marnewick 2014; OECD 2017; Ongori, Atambo \& Bosire 2015; Rungani \& Potgieter 2018). However, there have been concerns about their failure rate and their inability to gain a competitive advantage, especially in the current era of adoption of rapid information and communication technology (ICT).

In South Africa (SA), SMMEs operate in different environments such as cities and townships and are experiencing unique contextual challenges. Township SMMEs are faced with challenges when considering the adoption of ICTs (Marnewick 2014). Because of the barriers that township SMMEs face, they tend to be reluctant to adopt ICTs.

Township SMMEs are not very competitive as they have income below the poverty level and relatively high attrition rates (Cant 2017; Mukwarami \& Tengeh 2017; Nambiar, 
Sutherland \& Scheepers 2019). According to Khosla (2013) and Cant, Wiid and Hung (2015), South African township SMMEs seem to be lagging behind in terms of ICT adoption and they show no progress, as most are still confined to their traditional way of operating without incorporating ICTs.

To clearly realise the study's aim, a stepwise research process was implemented. The literature review was conducted to gain a deeper understanding of the environment of township SMMEs and their current status of ICT adoption. It is important to gain a deeper understanding of the environment of township SMMEs because of their uniqueness and different attributes that are influenced by their environment and their historical background. The importance of understanding the distinct differences between SMMEs operating in townships as opposed to those operating in the cities is necessary to inform interventions and policies directed towards SMMEs. The success of township SMMEs can positively have an effect on the challenges that SA is currently facing by reducing unemployment, creating jobs, fighting poverty, building safe, secure and sustainable communities, driving competitiveness with larger enterprises and increasing economic growth and development (Murithi 2017).

This study focusses on SMMEs located in townships and investigates the factors that influence their adoption of ICTs into their different business processes and value chains. Compared with SMMEs operating in the cities, SMMEs in a township can potentially positively contribute to socio-economic development, especially in the context of SA where a significant part of the economy is from the informal sector. The causes for township SMMEs to be lagging behind with regard to ICT adoption are not obvious. Various sectors have long appreciated the benefit of ICT adoption and recognised that when implemented effectively, ICT can contribute positively towards economic growth and social development. The adoption of ICT can allow township SMMEs to gain a competitive advantage, improve the sector positively and contribute towards the township economy. The South African government has directed stronger attention towards township SMME development and has acknowledged that SMMEs are the driving force of the township economy (Makhura 2018). Furthermore, there have been various interventions by the government to stimulate and support township SMMEs with various interventions such as technology hubs located in townships. However, this has not been well appreciated or achieved the objective set out by the government. Township SMMEs are unique and they require specific guidelines to promote ICT adoption compared with SMMEs operating in the cities. This implies that the adoption of ICT for township SMMEs will be different from those in the city. Bhorat et al. (2018) indicated that SMMEs in townships face greater challenges than those in the cities. Small, medium and micro-enterprises operating in townships are faced with unique challenges compared with those operating in the cities, such as lack of assets, quality housing, economic and social infrastructure networks (e.g., electricity and broadband) and skills (SACN 2016).

Various studies have been conducted around SMMEs in SA, precluding the township context (Cant et al. 2015; Ismail, Jeffrey \& Belle 2011; Mathu \& Tlare 2017; Pillay 2016; Turpin 2018). To better determine the factors affecting ICT adoption by township SMMEs and construct an ICT adoption framework, it is necessary to broadly understand the township environment, including their historical background.

Therefore, there is a need to review previous studies on ICT adoption by SMMEs in relation to township SMMEs' characteristics. At the same time, it is imperative to understand the factors influencing the adoption of ICT by South African township SMMEs and what kind of support and guidelines are required to promote ICT adoption.

Literature shows that there is a dearth of ICT adoption by township SMMEs (SME 2017). Various studies have been conducted in SA with regard to SMMEs' ICT adoption, but no literature studied the township SMMEs' perceptions or opinions towards ICT adoption. Furthermore, no framework for ICT adoption by township SMMEs exists. Studies conducted in SA related to the SMME context precluded the township SMME context (Cant et al. 2015; Ismail, Jeffery \& Van Belle 2011; Mathu \& Tlare 2017; Pillay 2016; Turpin 2018).

Therefore, this study addresses the gap in literature and provides guidelines that are necessary to consider when promoting ICT adoption within township SMMEs.

It is important to understand the challenges that township SMMEs face with regard to the successful adoption of ICT and what the impact thereof is. According to Khosla (2013) and Cant et al. (2015), South African township SMMEs seem to be lagging behind in terms of ICT adoption and they show no progress, as most are still confined to their traditional way of operating without any ICTs. Studies on ICT adoption have been conducted with little focus on township SMMEs.

For township SMMEs to fully participate in the economy, develop and grow, there is a need to have an in-depth understanding of the factors affecting ICT adoption. The adoption of ICTs by township SMMEs can contribute positively towards the South African economy, address challenges such as unemployment and create platforms for township SMMEs to gain a competitive advantage and participate in the global economy. Therefore, the identified research problem attempts to address the lack of research on the factors affecting ICT adoption by township SMMEs and to provide an ICT adoption framework for township SMMEs.

\section{Literature review}

To better determine the factors affecting ICT adoption by township SMMEs and construct an ICT adoption framework, it is necessary to broadly understand the township environment, and how they are defined, including 
their historical background. South Africa's townships are relics of the country's apartheid regime. The impact of past neglect, lack of investment, overpopulation and isolation from urban centres is still largely evident today.

\section{Definition of small, medium and micro-enterprises}

Arriving at a consensus regarding the definitions of SMMEs presents a challenge as every country applies its own definition, and there is no single internationally agreed-upon definition (Gbandi \& Amissa 2014; Gibson \& Van der Vaart 2008). Some countries attempt to use capital assets, whereas others use the skill of labour and turnover level (Ayyagari, Beck \& Demirguc-Kunt 2007). There are also those who still define SMMEs in terms of their legal status and method of production and size (Abor \& Quartey 2010). Keskin and Senturk (2010) assert that SMME definitions are mostly based on the size of their economic activity within a country and their level of development.

Defining an SMME has also recently been reviewed in the context of SA. Previously, the South African National Small Business (NSB) Act 102 of 1996 defined a small business as a separate entity that can be within any sector or sub-sector of the economy and which can be classified as a microenterprise, a very small enterprise, a small enterprise or a medium enterprise (Republic of South Africa 1996). The NSB Amendment Acts of 2003 and 2004 further define an SMME as a distinct business entity managed by one or more persons, which must meet certain specified criteria.

This study adopts the new definition as described by the South African government in 2019. According to the South Africa Government Gazette (2019), the new definition of SMMEs uses two proxies (employees and annual turnover) and excludes the original third proxy (total gross asset value) (SA Government Gazette 2019). This study thus defines an SMME as any small business regardless of its registration under law or tax, and it can be any entity or organisation which includes any person conducting small business activities in any sector.

\section{The historical overview of township small, medium and micro-enterprises}

The history of township SMMEs in SA dates back to the apartheid era - the period during which black people were prohibited from owning businesses and faced prosecution for engaging in any business activity (DTI 2008; Mtshali, Mtapuri \& Shamase 2017). Townships experienced segregation in terms of housing, education, health and libraries, amongst others (Ramchander 2007). Townships, often referred to as urban residential areas, were formed for the black population, usually beyond city limits. By contrast, the white population resided in suburbs or cities. Generally, every city had at least one, and often several, township(s) associated with it. The historical background of townships has a significant impact on how SMMEs operate their businesses on a daily basis in contemporary business environments. Even after becoming a democratic country, SA still seems to have well-structured geographical inequalities and challenges hindering the growth of township SMMEs.

\section{Township small, medium and micro-enterprises versus those operating in the cities}

Small business owners in townships were regarded as selfemployed during the apartheid era and most operate illegally (Mazwai 2017). In contrast, small business owners in cities were encouraged during this period, through legislation and other local authority ordinances, to participate freely in any form of small business activity without facing prosecution. The range of SMMEs operating in townships includes various sectors (Charman 2017), which may be similar to the SMMEs operating in the cities. This study argues that township SMMEs are very diverse, and because of socio-economic issues they have different needs and challenges compared with SMMEs in the cities. According to Davidsson and Honig (2003) and Rogoff, Lee and Suh (2004), some SMME owners or managers and their employees have limited or lack business skills; others are experienced, complex and dynamic in nature. The characteristics of township SMMEs should be studied in greater detail to understand how they affect the adoption of ICT. Small, medium and micro-enterprises operating in townships have unique attributes, such as their location where they operate, ICT infrastructure, access to ICT, business classifications (that can be seen as informal businesses), personal attitudes or attributes of SMME owners or managers, and levels of ICT skills or knowledge.

\section{The roles of township small, medium and micro-enterprises in contributing towards the economy}

Township SMMEs can play a vital role in curbing the challenges that South Africa is currently facing such as unemployment, poverty and inequality. The South African National Development Plan (NDP) indicated the importance of creating about 11 million jobs by the year 2020. The NDP further recognised the role of SMMEs towards achieving the set targets and the capability of SMMEs to act as the backbone of economic growth and development (National Development Plan 2030 2012). Township SMMEs are part of the South African economy, and they too play a vital role towards the growth of the economy. In Gauteng, SMMEs have created about 150000 jobs in a single year, and this was a result of government's support to SMMEs (Statistics South Africa 2015). Therefore, it is imperative that township SMMEs receive necessary interventions and support to address many of the challenges faced by the country (Mathu \& Tlare 2017).

\section{Challenges faced by township small, medium and micro-enterprises}

Literature shows that SMMEs may face common challenges such as access to finance. The biggest challenge can also be attributed to how SMMEs are regulated. In SA, an SMME is 
regarded as either a formal or informal business. Formal business are monitored, protected and taxed by the government, whereas the informal SMMEs are not regulated by the government. Formal SMMEs are well established, licensed, large and complex businesses that are predominantly concentrated in cities. Informal SMMEs are unregistered with the municipality or tax authority and they have fewer employees (International Labour Office [ILO] 2012). They are disconnected from the mainstream economy and face structural barriers that impact negatively on their growth potential (DTI 2008).

Township SMMEs are mainly informal, owned by marginalised people and have their own unique challenges.

According to Malefane (2013), most of the SMMEs in townships are informal and are used by the unemployed as a means to provide for basic needs. These informal SMMEs can be classified as hawkers, vendors and subsistence farmers, which usually include people unable to find paid jobs (Iwu et al. 2016; SEDA 2018). They have minimal assets and have income below the poverty level (Morris \& Zahra 2000).

Challenges that township SMMEs face when compared with those operating in the cities may be attributed by a lack of assets, such as quality housing, economic and social infrastructure networks (e.g. electricity, broadband) and skills (SACN 2016). Drodskie (2002) indicates that SMMEs in townships face greater challenges than those in the cities. With regard to ICT adoption, poor ICT infrastructure in townships may hinder the growth of SMMEs and add significant pressure in terms of the cost of running a successful business. According to the Global Entrepreneurship Monitor Report (Bhorat et al. 2018), infrastructure is an important factor to enable the development of SMMEs. Poor infrastructure can also inhibit successful adoption of ICT.

Table 1 shows some of the challenges that township SMMEs face. These are varied, regardless of the environment in which they operate. However, Lekhanya (2016) states that the challenges that SMMEs face may be internal or external, and they have a huge impact on the survival and the sustainability of the business.

It is true that ICT cannot be seen as 'adopt me', and all township SMME-related challenges will fade away as it is not a panacea to all problems faced by small businesses. Therefore, other challenges may not necessarily be resolved through the adoption of ICTs. Even though there is massive evidence of the importance of ICT adoption and the role it can play in growing the economy, there is still much-desired attention in SA in terms of issues of good governance.

Literature has shown the impact of ICT and the role it plays towards the growth and development of SMMEs (OECD 2017). Given the potential for ICTs to jumpstart socio-economic development, both developing and developed countries placed an emphasis on adopting ICTs to access digital opportunities. Various authors have alluded to the impact and role of ICTs towards economic development (Liljevern \& Karlsson 2017; Toader et al. 2018). Information and communication technology adoption by township SMMEs is necessary because it allows SMMEs to access markets, procure goods at reasonable costs, effectively manage relationships with stakeholders and customers, make evidence-based decisions and improve the efficiency and effectiveness of both its internal and external business processes. By so doing, SMMEs are endowed with higher levels of competitive advantage.

Neirotti and Raguseo (2017) agree that ICTs may create a competitive advantage in the SMME environment.

Given that there are few insights on ICT adoption frameworks for township SMMEs, various ICT adoption frameworks will not work for township SMMEs because of the unique characteristics of township SMMEs.

Chibelushi and Costello (2009) argue that understanding the ICT adoption models is vital and the scope of ICT adoption must be clearly articulated. If the scope of ICT adoption is misinterpreted, it may lead to a loss of investment and not add any value to the SMME.

TABLE 1: Challenges faced by township small, medium and micro-enterprises.

Challenges Reference

- Skills and knowledge Mrasi, Mason and Jere 2018

- Lack of finance Myeko and Iwu 2019

- Lack of relevant information on

government support

- Crime

- Absence of infrastructure

- Lack of support from stakeholders Mbonyani and Ladzani 2011

- Lack of legal knowledge

- Lack of funding

- Lack of business acumen

- Poor technological skills

- Lack of business acumen

- Lack of management skills

- Finance and obtaining credit

- Access to markets

- Developing relationships with customers

- Lack of education

- Lack of training

- Inadequate government support

- ICT education

- Lack of ICT awareness

- Poor management skills

- Access to funding

- Lack of infrastructure

- Poor government support

- Competition

- Product cost

- High inventory cost

- Poor marketing of the business

- Lack of business sustainability skills

- Lack of information

- Lack of resources

- Need for marketing

- Financial training

- Management training

- Collaboration between government and

stakeholders to provide adequate training

$\mathrm{ICT}$, information and communication technology. 


\section{Theoretical and conceptual grounding}

This study is anchored on the Actor Network Theory (ANT) and the Technology Acceptance Model (TAM). The conceptual grounding of the ANT and the TAM enabled the study to investigate the adoption of ICT by township SMMEs. According to Stone-Jovicich (2015) as well as Holmström and Stadleder (2001), ANT is a theoretical framework that describes the world as a network of hybrid (social and technological) actors. Human and non-human actors exist in a network of relationships. The ANT provides a framework where both social and technological factors can be studied (Elbanna 2009).

The ANT refers to an actor as something or someone that contributes in making a change or a difference. That is, 'something that acts, or to which activity is granted by another, an actant can literally be anything provided it is granted to be the source of action' (Latour 1996:373). Actors are defined as all entities that are able to connect texts, humans and money to more or less effectively build a world that is filled with other entities having their own history, identity and relations (Callon 1991). Actors or actants do not exist in a vacuum. Any act in the world is influenced by different factors, thus creating a network. The ANT revolves around and describes ongoing processes within such a network.

The key concepts from ANT are adopted for this study to form an ICT adoption actor network for township SMMEs, which consists of four major stages: (1) problematisation, (2) interessement, (3) enrolment and (4) mobilisation (Callon 1987). Problematisation involves actors defining the problem to be addressed by using the obligatory passage point (OPP). The actors within a network use OPP to exchange resolutions contributing to solving a problem (Callon 1987; Law 1992). Interessement involves an actor performing various actions to align with other actors or draw attention to collaborate on a given proposal. Enrolment involves negotiations amongst enrolled actors so that they reach an agreement on problems to be solved. Mobilisation involves the organising of support of controlling actors so that the passive agents are influenced in the right direction to follow consensus already formed and acts as spokesman (Law 1992). Consensus can be reached with the passive agents although it is possible that there will be rebels not following the consensus prompting for advocacy by controlling agents to continue throughout the engagement process (Callon 1987).

Conceptualised by Davis in 1989, the TAM explains adoption, acceptance and usage of ICTs (Awa, Ukoha \& Emecheta 2012). The TAM is espoused upon the 'perceived usefulness' (PU) and 'perceived ease of use' (PEOU) as two key theoretical constructs at the centre of explaining technology adoption by individuals (Davis, Bargozzi \& Warshaw 1989). Perceived usefulness and PEOU are generally used to articulate the degree of user acceptance of technology.
PU is defined as the user's subjective likelihood to use a particular technology that will improve his or her action, and PEOU refers to the degree to which the potential user expects the target technology to be effortless (Davis 1989). According to Davis (1989), the PU and PEOU are also directly influenced by other external factors that typically reflect political, cultural and social aspects. Political factors are centred on the impact of using technology in politics and political crises. Cultural factors encompass the set of beliefs, moral values, traditions, language and laws held in common by a nation, a community or other defined group of people. Social factors may include language, skills and facilitating conditions. A consumer's attitude to use technology is concerned with the user's evaluation of the desirability of employing an information system application. Furthermore, behavioural intention includes the measure of the likelihood of a person employing the application. Davis' TAM was suitable for this study because it investigates the perception or attitude-based antecedents of township SMME owners or managers towards ICT adoption.

\section{Motivation for the selection of actor network theory and Technology Acceptance Model}

The selection of the two models is used because firstly ANT allows the examination of human and non-human role players in ICT adoption (Latour 2005). Furthermore, the ANT assists in the successful analysis of the dynamic and complex ICT adoption by township SMMEs. On the other hand, the TAM complements the understanding of the factors influencing ICT adoption by SMMEs by explaining SMME owners' attitude or perception and decision-making processes with regard to ICT adoption.

Given the focus of this article, a combination of the ANT and TAM helps to identify a diverse range of actors (both internal and external) and the role they play in explaining the adoption of ICTs by township SMMEs.

Both ANT and TAM have their own strengths and weaknesses. The strength of the ANT in this study is the fact that it allowed for the identification and recognition of all role players (actors) involved within the township SMME context, thus allowing a deeper understanding of all factors affecting the ICT adoption by township SMMEs. The strength of the TAM is its ability to use the two main constructs that allow one to determine the intention to actual behaviour. Therefore, the TAM complements the ANT by further providing an opportunity to understand the perception or attitude of role players (SMME owners or managers) towards ICT adoption.

Both theories focus on ICT adoption and the emphasis is placed on human agency. Eze, Vera and Eze (2018) posit that studies on ICT adoption should be conducted keeping in view both the human and non-human actors and not in isolation. Linking both the ANT and TAM allowed gaining an understanding of the true nature of the factors affecting ICT adoption by township SMMEs. The combination of the 
ANT and TAM framework helped to identify and understand the ICT adoption, actors involved, actors' roles and interactions and the critical factors.

\section{Formulating an information and communication technology adoption framework for township small, medium and micro-enterprises}

When formulating an actor network diagram, the fundamental understanding should be emphasised based on the relationship of the actors in their own network. The diagrams provide the efficiency in revealing the interactions in the scope of the network. The diagrams also provide an efficient way to map out all the actors or role players.

For example, the township SMME network diagram may include customers, suppliers, government, ICT and the location of the SMMEs.

\section{Problematisation stage}

Firstly, key role players are identified and, in this case, the SMME owner or manager as human actors because they are directly or indirectly involved in the process of ICT adoption, either planning or implementation. Moreover, they are seen as the driving force of whether to adopt ICT. The SMME owners or managers have their own characteristics such as their age, level of education and ICT skills. This translates to the fact that township SMMEs rely heavily on the SMME owner or manager to survive because decision-making is primarily at the owner's discretion. Therefore, other role players (whether human or nonhuman) must co-exist with the SMME owner as the key role player and should not exist in segregation when formulating the ICT adoption process or the implementation of ICT. The identification of key role players (SMME owner or manager) allowed for the use of TAM because when using TAM one can answer the question of the perception or attitude of township SMME owners or managers towards ICT adoption. This is enabled by TAM's ability to determine the intention towards an actual behaviour by using its two constructs: PEOU and PU. Perceived Ease of Use and PU are variables used by the TAM suggesting that when SMME owners or managers are presented with ICT, there are various factors that determine whether the proposed ICT will be accepted or rejected. Township SMME owners or managers may adopt ICTs if they believe there is a benefit in terms of business growth or sustainability.

That is, if their perception towards ICT is not beneficial to their business enhancement, they will reject the adoption. The second variable of the TAM (PEOU) refers to the fact that township SMME owners or managers may adopt ICT if their perception around ICT to be adopted means they will be easy to use and not complex.

\section{Interessement stage}

In this stage, various actors or a particular actor within township SMMEs may interact with one another or form a collaboration for a particular action. For example, the type of ICT to be adopted, the cost of ICT and the infrastructure may collaborate for potential full utilisation of the technology. The interessement in this case is the alignment amongst the actors. Although the township SMME owner or manager may have the intention to adopt ICT, the cost of ICT may not create a desirable intention to adopt.

This study applied the interessement stage, which allows the various actors or a particular actor to perform actions and collaborate with other actors. This is achieved through defining the role of actor(s) in a township SMME network. Table 2 provides an illustration of actors within a township SMME network with regard to ICT adoption.

\section{Enrolment stage}

Actors within the township SMME network are established to ensure that collaborations and alignment are successful. The township SMME network is explored and various actors involved are discussed. At this stage, actors within the township SMME network are established to ensure that collaborations and alignment are successful.

The township SMME network includes owner or manager characteristics such as age, ICT skills and level of education.

\section{Mobilisation stage}

This stage is concerned with producing final results of the township SMME network. The framework shown in Figure 1 indicates the non-human actors, such as ICT infrastructure, ICT stakeholders, government support and competitive pressure, and recognises that without the interaction of the human with non-human actors, the ICT adoption will not be successful. Therefore, even though the human actor (SMME owner or manager) has the potential and readiness to

TABLE 2: Actors within the township network and illustration of their role.

\begin{tabular}{|c|c|c|}
\hline Actor & $\begin{array}{l}\text { Human or } \\
\text { non-human }\end{array}$ & Role(s) \\
\hline SMME classification & Non-human & $\begin{array}{l}\text { Classification, sector, age, annual } \\
\text { turnover, number of employees and } \\
\text { location }\end{array}$ \\
\hline $\begin{array}{l}\text { SMME owner or manager } \\
\text { characteristics }\end{array}$ & Human & Age, level of education, ICT skills \\
\hline SMME owner or manager & Human & Perceptions or attitude \\
\hline Government support & Non-human & Formulating ICT strategies or policies \\
\hline ICT stakeholders & Non-human & $\begin{array}{l}\text { Implementation policies township } \\
\text { SMME focussed }\end{array}$ \\
\hline ICT infrastructure & Non-human & The quality of ICT infrastructure \\
\hline Type of ICTs & Non-human & Hardware and software \\
\hline ICT cost & Non-human & Perceived cost \\
\hline Infrastructure or location & Non-human & $\begin{array}{l}\text { Access to location } \\
\text { Access or connectivity }\end{array}$ \\
\hline Competitive pressure & $\begin{array}{l}\text { Human or } \\
\text { non-human }\end{array}$ & $\begin{array}{l}\text { Customers } \\
\text { Innovation and pricing }\end{array}$ \\
\hline
\end{tabular}

ICT, information and communication technology; SMME, small, medium and micro-enterprise. 


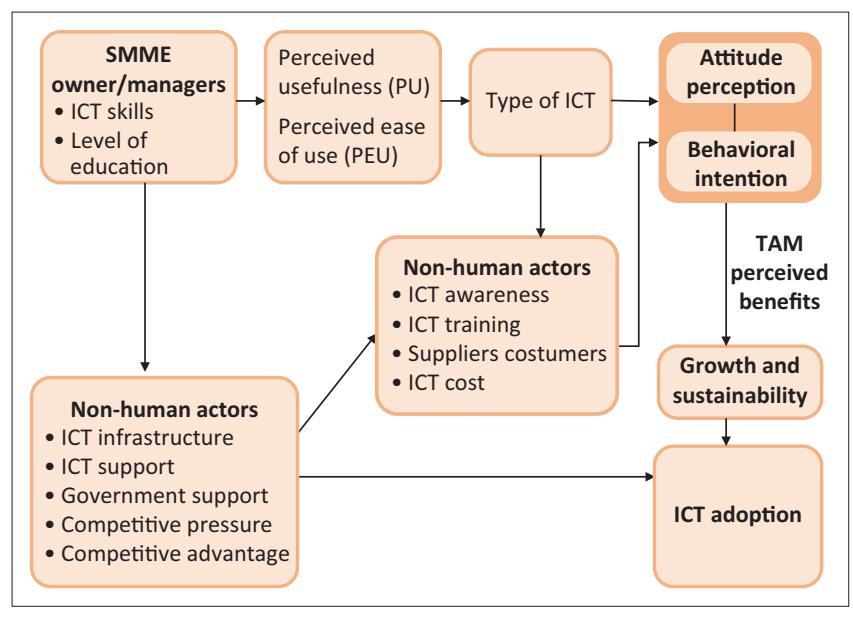

ICT, information and communication technology; SMME, small, medium and micro-enterprise; TAM, Technology Acceptance Model.

FIGURE 1: Information and communication technology adoption framework for township small, medium and micro-enterprises.

adopt ICT, the non-human actors may be a hindrance if they are not complementing the needs of the SMME owners.

Figure 1 shows that the role players are both external and internal within the SMME network. The ANT shows that there are various actors involved when considering the understanding of factors affecting ICT adoption by township SMMEs. Within an ANT, there is no role player that can possibly be independent, and as previously alluded, SMME owners are viewed as key role players because of the role they play as decision-makers in whether or not to adopt ICT for their businesses.

Figure 1 shows the interaction of all actors involved in ICT adoption by township SMMEs. If one actor fails to interact or does not act according to its role, the whole process may be unsuccessful. Understanding the relationship between actors and actually indicating that all actors need to work together are two important elements of ANT concepts.

External or internal actors in township SMMEs can include various roles. Some may seem to be active participants, whereas others are not active at all. In the case of the South African government, which is dedicated to playing a vital role in supporting township SMMEs, there is a dire need to ensure that proper support is aligned to the desired need by township SMMEs with regard to ICT adoption. External or internal actors can be anything from human to non-human such as members of the townships, municipalities, technologies, government or even users directly or indirectly involved in SMMEs.

\section{Methodology}

This study holds an epistemological view of interpretivism. This study adopted a multiple case study approach as a research strategy because the purpose was to gain an indepth understanding of township SMMEs' environments and the factors that affect ICT adoption by township SMME owners. This study adopted a multiple case study approach because the researcher examined the relationship between several variables such as the size of the business or the age of the business having an impact on ICT adoption. For all SMME categories, each one was evaluated as a single case and later compared against each case. The multiple case study strategy enabled the researcher to generate answers to questions related to how, what and why (Robson 2002). Researcher bias was reduced by ensuring that questions were thoughtfully posed and delivered in a way that allowed participants to reveal their true feelings without distortions. Through face-to-face interviews, SMME owners' or managers' real experiences were drawn and captured.

The study further aimed to identify the actors and their roles within the SMME environment when adopting ICTs and to develop an ICT adoption framework for township SMMEs. The study deployed a qualitative exploratory research method focussing on the 'why' questions, and it was used to describe the SMME characteristics and perceptions and their level of ICT adoption. Furthermore, the qualitative exploratory research method was also used to develop explanations about the factors that contribute to the level of the ICT adoption and why some types of ICTs are not used when some others are used. The target sample size was 21 SMME owners located in various zones within Soweto township. Data were collected by using interviews and observations conducted within the SMME's premises because they afforded the researcher an opportunity to determine whether ICTs were adopted or not. The purpose of observation in gathering data was for the researcher to understand what ICTs are adopted and to uncover how SMME owners define ICT and its meaning. Observation further afforded the researcher with the opportunity to see which SMME owners use ICT and their level of access to ICT.

The participants were identified based on the classification of being an SMME. The first brief observation of 37 SMMEs took place to determine whether an SMME is classified as small, medium or micro. The purpose of this first brief observation was to allocate the distribution of seven different zones in Soweto township as presented in Table 3. This was done to ensure that the sample is representative of the three types of SMMEs in different zones. Township SMMEs may not have the knowledge of whether they are classified as small, medium or micro. Finally, a target sample size of 21 was reached and Table 3 shows the various location or zones in Soweto from where participants were drawn.

The articipants were approached by the researcher either telephonically or with a visitation to the area where they operate, although this method was time-consuming. Visitation was deemed necessary because most of the township SMMEs operate in areas where the address is not visible or clear. The other benefit was that the researcher was able to explain the purpose of the study in detail, thus building report. 
The interview questions were divided into five sections. Section A focussed on the participants' demographic data (owners' or managers' age and level of education). Section B focussed on gaining more insights into the profile of the business operations and to verify the initial business classification. Section C focussed on determining the perceptions or attitudes towards ICT adoption and ICT access by SMME owners or managers. The section also investigated whether SMMEs are adopting or have adopted any ICT and the type of ICT they use. This was followed with an observation of the type of ICT used and what the ICT was used for. Section $\mathrm{D}$ focussed on ICT adoption, usage and support. Section E aimed to capture any critical information or comments by the participants not directly measured in the previous sections.

This study used thematic analysis to analyse the qualitative data. Thematic analysis has been defined as 'a method for identifying, analysing and reporting patterns (themes) within data' (Braun \& Clarke 2006:79). The researcher applied deductive thematic analysis because data were in line with each specific question asked in the interview by using Atlas. ti version 8 .

This study adopted the steps set out by Braun and Clarke (2006) when conducting thematic analysis:

- Familiarising yourself with your data: Data were transcribed, read and reread to allow the researcher to become familiar with the data. The researcher got involved with the data through reading and listening to the recordings before coding, thus allowing her to identify meanings and patterns.

- Generating codes: In this stage, the inductive coding involved labelling the segments of texts with codes.

- Searching for themes: At this stage, the researcher had various codes identified and codes were sorted into potential themes. A collection of themes emerged.

- Reviewing themes: At this stage, themes were refined. Themes that needed to be collated to others were grouped accordingly. Those that needed to be identified and subcomponents were also refined accordingly.

- Defining and naming themes: The researcher captured the meaning or essence of each theme and the aspect of the data with each theme.

\section{Ethical consideration}

The ethical clearance to conduct this study was obtained from the University of Johannesburg, College of Business and Economics (clearance number: CBEREC19SCiiS03).

TABLE 3: Locations or zones of respondents in Soweto.

\begin{tabular}{lccc}
\hline Location or zone & Medium business & Small business & Micro-business \\
\hline Vilakazi & 1 & 1 & 1 \\
Protea South & 1 & 1 & 1 \\
Protea Glen & 1 & 1 & 1 \\
Dobsonville & 1 & 1 & 1 \\
Diepkloof & 1 & 1 & 1 \\
Meadowlands & 1 & 1 & 1 \\
Pimville & 1 & 1 & 1 \\
\hline Total respondents in & $\mathbf{7}$ & $\mathbf{7}$ & $\mathbf{7}$ \\
each zone & & &
\end{tabular}

\section{Results and discussions}

The 21 township SMMEs participated in this study were from various sectors and included a funeral parlour, salons, construction, retail, trade and repair services, catering and accommodation, manufacturing, wholesale trade and social and community services. The SMMEs may be regarded as formal or informal. However, there was no evidence of whether they are regulated by the city government, pay tax and abide by the best and acceptable business practices. It is for this reason that they are classified as informal businesses.

\section{Owner or manager's characteristics}

Participants were examined by using the criteria of level of education, age and their position (owner or manager). The results as depicted in Table 4 revealed that the level of education for township SMME owners or managers is very good. The findings examined the relationship between the level of education and ICT adoption. Furthermore, it was deduced from the findings that the level of education of township SMME owners or managers is very good.

The age and level of education may be seen to be directly influencing the decision to adopt ICT. The ages of the 21 participants ranged from 22 to 59 (Table 5). The data show that about $80 \%$ of SMME owners or managers are over 30 years of age. Some prior literature has shown that age is a determinant of ICT adoption, indicating that younger people tend to adopt ICT more readily than the older generation (Harrison \& Rainer 1992; Ongori \& Migiro 2010).

\section{Owner's information and communication technology skills}

Lack of ICT skills has been cited by various authors as one of the barriers towards ICT adoption (Jaganathan et al. 2018; Mwila \& Ngoyi 2019; Yadav, Yadav, Malik 2019). This study revealed that ICT skills are one of the hindrances that affect the ICT adoption. Although the SMME owners or managers seem to have some level of secondary education, they have problems in their ICT skills. The findings have indicated that the reason they are not using other ICT is that they have no idea which ones are best or most suitable for their type of

TABLE 4: Level of education.

\begin{tabular}{lccccc}
\hline $\begin{array}{l}\text { Classification } \\
\text { of business }\end{array}$ & \multicolumn{5}{c}{ Frequencies } \\
\cline { 2 - 6 } & $\begin{array}{c}\text { Primary } \\
\text { education }\end{array}$ & $\begin{array}{c}\text { Secondary } \\
\text { education }\end{array}$ & Matric & $\begin{array}{c}\text { Higher } \\
\text { education }\end{array}$ & Total \\
\hline Small & 0 & 1 & 2 & 4 & $\mathbf{7}$ \\
Medium & 0 & 1 & 2 & 4 & $\mathbf{7}$ \\
Micro & 1 & 1 & 2 & 3 & $\mathbf{7}$ \\
\hline Total & $\mathbf{1}$ & $\mathbf{3}$ & $\mathbf{6}$ & $\mathbf{1 1}$ & $\mathbf{2 1}$ \\
\hline
\end{tabular}

TABLE 5: Age of owners or managers.

\begin{tabular}{lccccc}
\hline $\begin{array}{l}\text { Classification } \\
\text { of business }\end{array}$ & \multicolumn{5}{c}{ Frequencies } \\
\cline { 2 - 6 } & $\begin{array}{c}\mathbf{2 1 - 3 0} \\
\text { (years) }\end{array}$ & $\begin{array}{c}\mathbf{3 1 - 4 0} \\
\text { (years) }\end{array}$ & $\begin{array}{c}\mathbf{4 1 - 5 0} \\
\text { (years) }\end{array}$ & $\begin{array}{c}\mathbf{5 1 - 6 0} \\
\text { (years) }\end{array}$ & Total \\
\hline Small & 1 & 3 & 3 & 0 & $\mathbf{7}$ \\
Medium & 1 & 4 & 1 & 1 & $\mathbf{7}$ \\
Micro & 2 & 2 & 1 & 2 & $\mathbf{7}$ \\
\hline Total & $\mathbf{4}$ & $\mathbf{9}$ & $\mathbf{5}$ & $\mathbf{3}$ & $\mathbf{2 1}$ \\
\hline
\end{tabular}


business, and they do not have the skills necessary to become more familiar with possible ICT.

They also indicated that having any ICT does not necessarily mean it is beneficial to them as they need a specific ICT that will enable them to either operate their business effectively or encourage growth.

\section{Type of information and communication technology used and reasons for usage}

This section aimed at answering the question regarding the perception or opinion by township SMME owners or managers with regard to ICT adoption and access. The type of ICT used and the reasons for its usage varied amongst all 21 participants, as shown in Table 6. Some used ICT such as mobile phones for both personal and business operations.

Although there are various types of ICTs that can be used to enhance and potentially grow the township SMMEs, it seemed the SMMEs only adopted what was familiar to them regardless of whether it adds value to the business or not.

\section{Reasons for non-adoption of information and communication technologies}

There are various reasons cited for the non-adoption of ICTs. Table 7 shows the reasons why township SMMEs do not adopt ICTs.

In relation to the TAM, PE and PEOU are the factors that influence ICT adoption. The perception or opinion towards ICTs is seen as a major issue affecting ICT adoption by township SMMEs. The perceptions or opinions of what is viewed as 'complex ICTs' are associated with sensitive information such as financial online business transactions resulting in these applications not being adopted, even though participants owned mobile phones capable of the functionalities of online transactions.

There seemed to be a belief that the ICT infrastructure in the township is poor compared to the cities, thus township SMMEs may be disadvantaged when it comes to ICT access, specifically in terms of connectivity and access. This can be problematic especially for SMMEs that are relying on ICTs for competitive advantage and growth.

TABLE 6: Type of information and communication technologies and reasons for using current information and communication technologies.

\begin{tabular}{ll}
\hline Type of ICTs used & Reasons for usage \\
\hline Laptop & Typing and banking \\
Printer & Printing work documents \\
Cash tills & Cashing in \\
Landline & Business calls from suppliers and customers \\
& Used for banking \\
Internet & Access various websites, suppliers and purchasing stock \\
Wi-Fi & Accessing the Internet and downloading items \\
Social media & Marketing, communication with customers and advertising \\
Mobile applications & - \\
Scanner & Scanning suppliers documents \\
Server & Back up information \\
\hline
\end{tabular}

ICTs, information and communication technologies.

\section{Factors that will influence information and communication technology adoption}

\section{Information and communication technology support to improve traditional business operations}

ICT adoption is influenced by the need to effectively improve business operations, such as using ICT that will enable them to operate their business transaction effectively.

\section{Information and communication technology support to gain a competitive advantage}

Competitive pressure was mentioned as a threat. Participants indicated that the larger enterprises were posing a threat to their businesses because of their ability to utilise complex and expensive ICT. Another influence was from the competitive pressure by suppliers who are using ICT for their operations.

\section{Information and communication technology support to gain increase and retain customers}

Customers make decisions with regard to which businesses to use based on the ICT the SMMEs have, especially the ability to conduct business through the Internet. Therefore, township SMMEs experience pressure from customers on the usage of ICT.

\section{Improve competitive advantage}

Participants mentioned that they had the desire to sustain their business, and the adoption of ICT would grant them the ability to gain a competitive advantage over their counterparts. They believed that ICT would assist them to stay competitive and grow their business.

\section{Support for growth and sustainability}

Overall, the 21 participants perceived ICT adoption as a necessity towards growth and sustainability for their business. They perceived ICT adoption as a necessity to grow their businesses and a medium through which their business operations could be enhanced. A total of 20 participants indicated that there were benefits associated with ICT adoption. Only one participant commented that they had no knowledge of any ICT benefits for their business. However, interestingly, they agreed that there are benefits with regard to ICT adoption for businesses, but not their type of business.

TABLE 7: Reasons for non-adoption of information and communication technologies.

\begin{tabular}{ll}
\hline $\begin{array}{l}\text { Reasons for non-adoption } \\
\text { of ICTs }\end{array}$ & Quote from participant \\
\hline Perceived high cost of ICTs & $\begin{array}{l}\text { 'It is a cost, ICTs are not that cheap, cost is one of the } \\
\text { main issues when it comes to success of our business, } \\
\text { we cannot spend on ICTs that will not work'. } \\
\text { (Participant 19, Secondary school, 40 year-old) }\end{array}$ \\
ICT infrastructure & $\begin{array}{l}\text { 'Connectivity can make you cry here, downloading a } \\
\text { small file is disastrous compared to downloading a file } \\
\text { in Joburg city'. (Participant 14, Degree, 30 year-old) }\end{array}$ \\
ICT awareness or ICT & $\begin{array}{l}\text { 'I have no idea if there are any ICTs for my type of } \\
\text { business. True I don't know where to start, even if you } \\
\text { give me money I will not know which technology to } \\
\text { buy'. (Participant 11, Primary school, 59 year-old) }\end{array}$ \\
\hline
\end{tabular}

ICTs, information and communication technologies. 
Information and communication technology that is affordable

The participants indicated that they could adopt ICT, but the cost of ICT was not affordable. High cost was mostly associated with data and access to Wi-Fi. Participants felt they only effectively used their mobile phones when they had data, and cost was a determining factor when using data.

\section{Information and communication technology support towards accessibility or connectivity}

Poor connectivity and accessibility, such as slow broadband, may have an impact on ICT adoption. The poor infrastructure in townships remained a barrier for SMMEs to access the Internet or use their ICT mobile apps.

\section{Government support}

Participants' overall view with regard to ICT support was that there was currently no ICT support in townships, therefore, leaving township SMMEs stranded when seeking ICT support. Although there have been ICT initiatives in Soweto (COJ 2015), all participants indicated that they were not aware of such support. This could mean that participants had not seen the impact of the ICT support or lacked information on it. This is a concern if there is no visibility of the available ICT-support programmes.

The overall general views from participants were directed at the government with a plea to support township SMMEs. Participants were relaying their fears of not adopting ICT as a setback towards growth and reducing the unemployment rate in SA.

This study makes a significant theoretical contribution to the ICT adoption body of knowledge by examining the five existing ICT adoption theories that have mostly addressed the ICT adoption phenomena from developed and developing countries. The literature helped to construct an ICT adoption framework for township SMMEs by using a combination of the TAM and ANT. The study provides an ICT adoption framework for township SMMEs.

Furthermore, it revealed that there are various role players (human and non-human) and illustrated how they interact with each other. This study filled the identified research gap by revealing that ICT adoption by township SMMEs is not a one-size-fits-all intervention; it is dynamic and involves various factors that are either internal or external.

From a practical perspective, this study makes contributions by providing factors to be considered when encouraging ICT adoption by township SMMEs. This study also contributes to the SMME owners' or managers' understanding of the factors that are necessary when considering ICT adoption. Small, medium and micro-enterprise owners or managers are the key decision-makers, which makes it essential to understand the factors to be considered when they are adopting ICTs. Finally, the study contributes to various stakeholders that invest in interventions towards ICT adoption for township
SMMEs. This should assist the stakeholders to be visible and also to provide necessary ICT interventions for township SMMEs. The interventions can include ICT support, such as ICT training and ICT skills.

\section{Conclusion}

The success of township SMMEs in the developing world context continues to be one of the most critical methods of moving nations forward in terms of addressing socioeconomic challenges such as unemployment, economic participation and rectifying an unequal and unjust society. The findings further revealed that township SMMEs' perceptions or attitude towards ICT adoption vary. Although there is a general consensus regarding the perceived benefits towards ICT adoption, there were also varying factors revealed such as ICT cost, ICT awareness, ICT support and ICT infrastructure. The findings revealed that there is a perception that there must be interventions tailored to their needs in terms of the type of ICTs they should adopt. There was also a concern of adopting ICTs that are not relevant to them compared with larger enterprises which may rely on expert ICT practitioners for adoption. This implies that SMME owners perceive ICT as either not easy to use or complicated, resulting in a high possibility of non-adoption. This corresponds with studies that revealed SMMEs are not positioned to employ skilled ICT employees, which has an impact on ICT adoption (Agboh 2015; Okundaye et al. 2019)

What emerged from this study is the perception of township SMMEs towards ICT adoption. Although there has been an acknowledgment of the importance of adopting ICTs to grow and sustain the township SMMEs, it is recommended that before any interventions are made or support is implemented, all factors that affect ICT adoption must be addressed, such as ICT training and ICT support. In conclusion, even though there have been numerous interventions put in place to support township SMMEs by the government and private sector, they do not seem to be successful in stimulating the township SMMEs. It is important to have guidelines that will encourage ICT adoption by township SMMEs. Township SMMEs are also the driving force of the economy in SA and they should not be left behind when it comes to the digital economy. The sustainability of township SMMEs is imperative and can happen if the right interventions and guidelines are carefully formulated.

In summary, this study unveils the various challenges and perceptions towards ICT adoption by township SMMEs. Small, medium and micro-enterprises are complex in nature and dynamic; therefore, they require interventions through in-depth engagement to explore their needs and reasons behind ICT adoption or non-adoption.

\section{Acknowledgements}

The authors are grateful for the support and time received from the University of Johannesburg. 


\section{Competing interests}

The authors declare that there are no financial or personal relationships that may have inappropriately influenced them in writing this article.

\section{Authors' contributions}

Both the authors have contributed equally to the work.

\section{Funding information}

This study received no specific funding from any agency in the public, commercial or non-profit sectors.

\section{Data availability statement}

Data sharing is not applicable to this article as no new data were created or analysed in this study.

\section{Disclaimer}

The views and opinions expressed in this article are those of the authors and do not necessarily reflect the official policy or position of any affiliated agency of the author.

\section{References}

Abor, J. \& Quartey, P., 2010, 'Issues in SME development in Ghana and South Africa', International Research Journal of Finance and Economics 39, 218-228.

Agboh, D., 2015, Drivers and challenges of ICT adoption by SMES in Accra metropolis, Ghana.6-1, viewed 18 September 2017, from www.www.aabri.com/ manuscripts/142044.pdf

Ayyagari, M., Beck, T. \& Demirguc-Kunt, A., 2007, 'Small and medium enterprises across the globe', Small Business Economics 29(4), 415-434. https://doi. org/10.1007/s11187-006-9002-5

Awa, H., Ukoha, O. \& Emecheta, B., 2012, 'Integrating TAM and TOE frameworks and expanding their characteristic constructs for e-commerce adoption by SMEs', 571-588. https://doi.org/10.28945/1676

Bhorat, H., Asmal, Z., Lilenstein, K. \& Van der Zee, K., 2018, SMMES in South Africa: Understanding the constraints on growth and performance, Development Policy Research Unit Working Paper 201802, Development Policy Research Unit, University of Cape Town, Cape Town.

Braun, V. \& Clarke, V., 2006, 'Using thematic analysis in psychology', Qualitative Research in Psychology 3(2), 77-101. https://doi.org/10.1191/1478088706 qp063oa

Callon, M., 1987, 'Society in the making: The study of technology as a tool for sociological analysis', in T.P. Hughes, W.E. Bijker \& T.J. Pinch (eds.), The social construction of technological systems: Newdirections in the sociology and history of technology, pp. 83-103, MIT Press, Cambridge, MA.

Callon, M., 1991, 'Techno-economic networks and irreversibility', in J. Law (ed.) A sociology of monsters: Essays on power, technology and domination, pp. 132-161, Routledge, London.

Cant, M.C., 2017, 'The availability of infrastructure in townships: Is there hope for Township businesses?', International Review of Management and Marketing 7(4) 108-115.

Cant, M.C., Wiid, J.A. \& Hung, Y., 2015, 'Internet-based ICT usage by South African SMEs: Are the benefits within their reach?', Problems and Perspectives in Management 13(2-si), 444-451.

Charman, A., 2017, 'Micro-enterprise predicament in township economic development: Evidence from Ivory Park and Tembisa', South African Journal of Economic and Management Sciences 20(1), 1-14. https://doi.org/10.4102/sajems.v20i1.1617

City of Johannesburg, 2015, Integrated Development Plan: 2015/2016, viewed n.d., from https://www.joburg.org.za/documents/Pages/Key\%20Documents/ Intergrated\%20Development\%20Plan/Integrated-Development-Plan.aspx.

Chibelushi, C. \& Costello, P., 2009, 'Challenges facing the W.Midlands ICT-oriented SME's', Journal of Small Business and Enterprise Development 16(2), 210-239. https://doi.org/10.1108/14626000910956029

Davidsson, P. \& Honig, B., 2003, 'The role of social and human capital among nascent entrepreneurs', Journal of Business Venturing 18(3), 301-331. https://doi. org/10.1016/S0883-9026(02)00097-6

Davis, F., 1989, 'Perceived usefulness perceived ease of use and user acceptance of information technology', MIS Quarterly 13(3), 319-340. https://doi. org/10.2307/249008
Davis, F.D., Bargozzi, R.P. \& Warshaw, P.R., 1989, 'User acceptance of computer technology: A comparison of two theoretical models', Management Science 35(8), 982-1003. https://doi.org/10.1287/mnsc.35.8.982

Department of Trade and Industry (DTI), 2008, Business in the information age: International benchmarking report, Department of Trade and Industry, London.

Drodskie, P., 2002, Job creation and productivity through accessing finance. Productivity, Official publication of the National Productivity Institute of South Africa, Pretoria, April-May, 19-20.

Elbanna, S., 2009, 'Determinants of strategic planning effectiveness: Extension of earlier work', Journal of Strategy and Management 2(2), 175-187. https://doi. org/10.1108/17554250910965326

Eze, C.S., Vera, C. \& Eze, C., 2018, 'Examining information and communication technology (ICT) adoption in SMEs: A dynamic capability approach', Journal of Enterprise Information Management 31(2), 338-356. https://doi.org/10.1108/ JEIM-12-2014-0125

Gbandi, E. \& Amissah, G., 2014, 'Financing options for small and medium enterprise (SMEs) in Nigeria', European Scientific Journal 10(1), 324-340.

Gibson, T. \& Van der Vaart, H.J., 2008, Defining SMEs: A less imperfect way of defining small and medium enterprises in developing countries, Brookings Global Economy and Development, viewed 11 March 2015, from www.brookings.edu/ /media/ research/files/papers/2008/9/development\%20gibson/09_development gibson.pdf.

Harrison, A.W., Jr. \& Rainer, R.K., 1992, 'The influence of individual differences on skill in end-user computing', Journal of Management Information Systems 9(1), 93-111. https://doi.org/10.1080/07421222.1992.11517949

Holmström, J. \& Stadler, F., 2001, 'Drifting technologies and multi-purpose networks: The case of the Swedish cash card', Information and Organization 11(3), 187-206. https://doi.org/10.1016/S1471-7727(01)00004-5

International Labour Office, 2012, Statistical update on employment in the informal economy, International Labour Office, Geneva.

Ismail, R., Jeffery, R. \& Van Belle, J.P., 2011, 'Using ICT as a value adding tool in South African SMEs', Journal of African Research in Business \& Technology (2011), 1-12. https://doi.org/10.5171/2011.470652

Iwu, C.G., Gwiya, S., Tengeh, R., Cupido, C. \& Maso, R.B., 2016, 'The unique role of survivalist retail entrepreneur in job creation and poverty reduction: Implications for active stakeholder participation', Acta Universitatis Danubius Economica 12(4), 16-37.

Jaganathan, M., Ahmad, S., Ishak, K.A., Nafi, S.T.N. \& Uthamaputhran, L., 2018 'Determinants for ICT adoption and problems: Evidence from rural based small and medium enterprises in Malaysia', International Journal of Entrepreneurship 22(4), n.p.

Keskin, H. \& Senturk, C., 2010, 'The importance of small and medium-sized enterprises (SME)s in the economies. SWOT analyses of the SME sector in Turkey and Albani', Journal of Faculty of Economics and Administrative Sciences 3(1), 116-132.

Khosla, B., 2013, ICT: SMEs cannot afford to be laggards, Expert Voice, Salt Lake City, UT.

Latour, B., 1996, 'On actor-network theory: A few clarifications', Soziale Welt 25(3) 369-381.

Latour, B., 2005, Reassembling the social: An introduction to actor-network theory, Oxford University Press, New York, NY.

Law, J., 1992, Notes on the theory of the actor-network: Ordering, strategy, and heterogeneity', Systems Practice 5(4), 379-393. https://doi.org/10.1007/ heterogeneity
BF01059830

Lekhanya, L.M., 2016, Rural entrepreneurship promotional strategy in South Africa: Concepts, practice and theories, Virtus Interpress, Sumy.

Liljevern, J. \& Karlsson, E., 2017, 'ICT investment and the effect on economic growth: A comparative study across four income groups', Student thesis, Jönköping University, Jönköping.

Makhitha, K.M., 2016, 'Challenges impacting on small independent retailers performance in Soweto, Johannesburg in South Africa', Investment Management and Financial Innovations 13(3-1), 258-266. https://doi.org/10.21511/imfi.13 (3-1).2016.12

Makhura, D., 2018, State of the Province address delivered. Gauteng Provincia legislature, Johannesburg, viewed 11 May 2018, from https://mg.co.za/ article/2018-02-26-read-in-full-premiermakhuras-gauteng-sopa-2018.

Malefane, S.R., 2013, 'Small, medium and micro enterprises and local economic-base restructuring: A South Africa local government perspective', Journal of Public Administration 48(4), 671-690.

Marnewick, C., 2014, 'Information and communications technology adoption amongs township micro and small business: The case of Soweto', South African Journal of Information 16(1), 1-12. https://doi.org/10.4102/sajim.v16i1.618

Mathu, K. \& Tlare, M.T., 2017, 'The impact of IT adoption in SMEs supply chains: A case of Gauteng and Free State provinces of South Africa', South African Journal of Business Management 48(3), 63-71. https://doi.org/10.4102/sajbm. v48i3.36

Mazwai, T., 2017, The great township business summit, Business Report, 13 June, University of Johannesburg, Johannesburg.

Mbonyane, B. \& Ladzani, W., 2011, 'Factors that hinder the growth of small businesses in South African townships', European Business Review 23(6), 550-560. https:// doi.org/10.1108/09555341111175390

Moos, M. \& Sambo, W., 2018, 'An exploratory study of challenges faced by smal automative business in townships: The case of Garankuwa, South Africa', Journal automative business in townships: The case
of Contemporary Management 14, 467-494. 
Morris, M.H. \& Zahra, S., 2000, 'Adaptation of the business concept over time: The case of historically disadvantaged South African owner/managers', Journal of Small Business Management 38(1), 92-100.

Mrasi, A., Mason, R.B. \& Jere, A., 2018, 'Critical skills and knowledge to succeed in the township liquor retail industry', Journal of Business and Retail Management Research 12(3), 26-35. https://doi.org/10.24052/JBRMR/V12IS03/ART-03

Mtshali, M., Mtapuri, O. \& Shamase, S.P., 2017, 'Experiences of black-owned smal medium and micro enterprises in the accommodation tourism-sub sector in selected Durban townships, KwaZulu-Natal', African Journal of Hospitality, Tourism and Leisure 6(3), 130-141.

Mukwarami, J. \& Tengeh, R., 2017, 'Sustaining native entrepreneurship in South African townships: The start-up agenda', International Economics 13(14), 332-345.

Mukwarami, J., Tengeh, R.K. \& Iwu, C.G., 2018, 'Success factors of immigrant-owned informal grocery shops in South African townships: Native shop-owners' account' Journal of Distribution Science 16(3), 49-57. https://doi.org/10.15722/ jds.16.3.201803.49

Murithi, S., 2017, 'African small and medium enterprises (SMEs) contributions, challenges and solutions', European Journal of Research and Reflection in Management Sciences 5(1), 36-48.

Mwila, M. \& Ngoyi, L., 2019, 'The use of ICT by SMEs in Zambia to access business information services and investments: Barriers and drivers', Journal of Global Entrepreneurship Research 9(15), 1-16. https://doi.org/10.1186/s40497-019-0145-7

Myeko, Z. \& Iwu, C.G., 2019, 'Obstacles faced by African copreneurs in Black Townships
of the Western Cape, South Africa', Journal of Reviews on Global Economics 8, 1-11. https://doi.org/10.6000/1929-7092.2019.08.01

Nambiar, Y., Sutherland, M. \& Scheepers, C.B., 2019, 'The stakeholder ecosystem of women entrepreneurs in South African townships', Development Southern Africa 37(1), 70-86. https://doi.org/10.1080/0376835X.2019.1657001

National Development Plan 2030, 2012, National Planning Commission, The Presidency, Republic of South Africa, Pretoria.

Neirotti, P. \& Raguseo, E., 2017, 'On the contingent value of IT-based capabilities for the competitive advantage of SMEs: Mechanisms and empirical evidence', Information \& Management 54(2), 139-153. https://doi.org/10.1016/j.im.2016.05.004

Ntsika Enterprise Promotion Agency Annual Review, 2001, State of small business development SA, Ntsika, Johannesburg.

OECD, 2017, Enhancing the contributions of SMEs in a global and digitalised economy, OECD Publishing, viewed 03 February 2019, from http://www.oecd.org/cfe/ leed/1918307.pdf

Okundaye, K., Fan, S. \& Dwyer, R., 2019, Impact of information and communication technology in Nigerian small-to medium-sized enterprises', Journal of Economics, Finance and Administrative Science 24(47), 29-46. https://doi.org/10.1108/ JEFAS-08-2018-0086

Ongori, H., Atambo, R. \& Bosire, D., 2015, 'Challenges faced by small and medium enterprises in Kenya: Theoretical argument', International Journal of Innovative Research \& Studies 5, 1-17

Ongori, H. \& Migiro, S.O., 2010, 'Information and communication technology adoption: A literature review', Journal of Chinese Entrepreneurship 2(1), 93-104. https://doi.org/10.1108/17561391011019041
Phikiso, Z. \& Tengeh, R.K., 2017, 'Challenges to inter-family succession in South African townships', Academy of Entrepreneurship Journal 23(2), 1-13.

Pillay, P., 2016, 'Barriers to information and communication technology (ICT) adoption and use amongst SMEs: A study of the South African manufacturing sector', Master thesis, University of the Witwatersrand, Johannesburg.

Ramchander, P., 2007, 'Township tourism: Blessing or blight? The case of Soweto in South Africa', in G. Richards (ed.), Cultural tourism: Global and local perspectives, pp. 39-67, Haworth Press, New York, NY.

Republic of South Africa, 1996, National Small Business Act No. 102 of 1996 Government Printer, Pretoria, viewed 21 August 2017, from http://www.thedti. gov.za/sme_development/docs/act.pdf.

Robson, C., 2002, Real World Research: A Resource for Social Scientists and Practitioner-Researchers, 2nd edn., Blackwell Publishers Ltd., Oxford.

Rogoff, E.G., Lee, M. \& Suh, D., 2004, “"Who done it?” Attributions by entrepreneurs and experts of the factors that cause and impede small business success', Journal of Small Business Management 42(4), 364-376. https://doi.org/10.1111/j. 1540-627X.2004.00117.x

Rungani, E.C. \& Potgieter, M., 2018, 'The impact of financial support on the success of small, medium and micro enterprises in the Eastern Cape province', Acto Commercii 18(1), a591. https://doi.org/10.4102/ac.v18i1.591

Small Enterprise Development Agency (SEDA), 2018, 1st quarter, SMME Quarterly Update, Small Enterprise Development Agency (SEDA), Pretoria.

SME South Africa, 2017, The state of SA's township entrepreneurship, viewed 02 July 2018, from https://www.smesouthafrica.co.za/15427/The-state-of-SAs-township entrepreneur ship/.

South Africa Government Gazette, 2019, National skills development plan 2030 Department of Higher Education and Training, No. 42290, Government Gazette, Pretoria.

State of South African Cities Report (SACN), 2016, State of South African cities report 2016, State of South African Cities, Johannesburg.

Statistics South Africa, 2015, Quarterly labour force survey, Statistics South Africa, Pretoria.

Stone-Jovicich, S., 2015, 'Probing the interfaces between the social sciences and social-ecological resilience: Insights from integrative and hybrid perspectives in the social sciences', Ecology and Society 20(2), 25. https://doi.org/10.5751/ES07347-20022

Toader, E., Firtescu, B.N., Roman, A. \& Anton, S.G., 2018, 'Impact of information and communication technology infrastructure on economic growth: An empirical assessment for the EU countries', Sustainability 10(10), 1-22. https://doi. org/10.3390/su10103750

Turpin, M., 2018, 'Assessing South African ICT4D research outputs: A journal review', South African Computer Journal 30(1), 108-127. https://doi.org/10.18489/sacj. v30i1.541

Yadav, D., Yadav, J. \& Malik, R., 2019, 'E-HRM: A Paradigm Shift in HR Practices and its Effects on Perception of Employees Towards Accepting This New Technology', Indian Journal of Management 12(2),23-39. https://doi.org/10.17010/pijom/2019/ v12i2/141754 